Original Research Reports

\title{
Empowered and Resilient: Educating Young People in Neoliberal Ideology
}

\author{
Horacio Espinosa Zepeda ${ }^{1,2}$ \\ [1] Observatory for the Anthropology of Urban Conflict (OACU), Barcelona, Spain. [2] Faculty of Psychology and Education Sciences, Universitat Oberta de \\ Catalunya, Barcelona, Spain.
}

Journal of Social and Political Psychology, 2021, Vol. 9(1), 172-186, https://doi.org/10.5964/jspp.6513

Received: 2020-05-21 • Accepted: 2020-12-10 • Published (VoR): 2021-04-20

Handling Editor: Hélder Alves, Universidad Autónoma de Madrid, Madrid, Spain

Corresponding Author: Horacio Espinosa Zepeda, 153 Rambla Badal, 7 floor, 3 door, Barcelona 08028, Spain. E-mail: horacio.espinosa.zepeda@gmail.com

\begin{abstract}
This article recovers the concept of "Ideology", anathematised by postmodern hegemony; here, taken out of the theoretical opprobrium in which it is found, I use it to carry out a critique of a youth-oriented community development program in the city of Barcelona. This approach should not be an exception, given that young people are so mercilessly bombarded with social programs elaborated around clearly ideological concepts such as "resilience" or "empowerment". Contrary to a certain commonplace narrative that defends the withdrawal of the state while facing the forces of the market, that process of neoliberal ideologisation is carried out not only with the acquiescence of states, but also with their active participation. The analysis of a public program such as this one shows, empirically, how governments are complicit with market forces through programs that transmit and put into practice neoliberal ideology.
\end{abstract}

\section{Keywords}

ideology, neoliberalism, youth, resilience, empowerment

"Ideology makes individuals 'act all by themselves', without there being any need to post a policeman behind each and every one of them."

Louis Althusser

\section{Presentation}

The context of analysis of this work is the city of Barcelona, in the framework of the qualitative evaluation I conducted of 'Cabal Musical', an initiative that aims at "accompanying and supporting young musical talents" who come from "disadvantaged social environments" (La Hidra Cooperativa, 2018); it is a program promoted in a public-private agreement between the music teaching academy El Taller de Músics and the City Council of Barcelona. The program has been applied to the so-called 'Franja Besòs' (Besòs strip), a territory whose indicators reveal low development and high social exclusion (Ajuntament de Barcelona, 2013).

'Cabal Musical' ['Caudal Musical' in Spanish, hereafter "C.M."] uses the metaphor of a river to describe each of the phases, through which the program passes. Its "birth" would correspond to the preliminary phases of promotion, call and selection; it would consist of seeking alliances in the territory, especially with neighbourhood youth associations ('casals de joves'), neighbourhood groups ('casals populars'), as well as civic, social and cultural centers. The "course" corresponds to the training part, which has a semi-school-based format; the course is designed to contain $50 \%$ of musical aspects and another 50\% dedicated to aspects related to entrepreneurship, the creation of a brand and empowerment strategies, as well as other aspects such as dissemination, image, social networks, etcetera. The last phase -the "outflow"refers to the professional "fit" of the artists in a post-cabal context; essentially, it is a matter of generating different 
strategies for promoting the groups by using the institutional channels available. The most commonly used one consists of organizing concerts or helping groups/soloists to set up presentations.

Throughout the fieldwork I focused on developing qualitative indicators which allowed me to generate and collect complementary information to that already collected daily by the program itself through quantitative methodologies. My objective was to avoid evaluation methods that are more typical of market analysis or classic administration (quantitative and short-term, in terms of benefits or assistance indicators) and to incorporate qualitative evaluation indicator systems that would reveal more about aspects, such as the degree of C.M.'s social impact or its territorial fit.

Pre-existing information sources were prioritised, as well as primary data collection. The research and official report addressed to the City Council was prepared by myself on behalf of La Hidra Cooperativa, the entity that was commissioned to evaluate the program. However, the present article is an analysis of the analysis contained in the report previously submitted to the City Council of Barcelona; the present text, written in an academic approach, has been self-financed, and all responsibility for it falls on myself.

\section{Some Methodological Notes}

At the methodological level, the quotes from the different participants were extracted from focus groups as well as open- and semi-structured interviews, following a qualitative approach in both data collection and analysis. Drawing from a methodological tradition that tries to overcome positivism, I conducted interviews following these considerations: 1) the interviewee and the interviewer possess the same reflexive capacity and 2) therefore the "specificities of each case (ideographic research)" must be respected, 3) as well as "the particular meanings that are generated on each occasion (hermeneutic research)" (Parker, 2004b, p. 23). The qualitative interview is therefore not merely an instrument for collecting data, but rather an artefact that favours dialogue and reflection (methodological dialogism).

In this sense, it is important to point out that, in the design of an in-depth and semi-structured interview guide, it is not valid to assume that the same question will have the same meaning for all interlocutors and in all contexts. Therefore, it is essential to orient the questions towards each of the positions encountered. This does not guarantee anything, but it does facilitate the search for divergence and variety. Thus, more than a questionnaire, the guide should resemble a list of basic themes or aspects of interest to be investigated.

Once the interviews were completed and duly transcribed, I continued reviewing the material by carrying out a thematic categorical analysis following the paradigm of critical social psychology (Vázquez, 1994) and elements of critical discourse analysis, especially the importance of ideology (Parker, 2004a). For the thematic categorisation of the interviews I used the ATLASti software.

With regard to the elaboration of categories, some considerations must be made. First of all, it should be borne in mind that, because a transcript is not the interview itself, it is not the material for analysis. Indeed, the transcript is the "impoverished record" (Burman, 2004, p. 80) of an event where, in addition to words, there were gestures, movements, a setting, an atmosphere, a sound environment, interruptions, glances, revealing or mysterious silences, etcetera. These situational and rather plastic emotional or vaporous aspects are part of the construction of the event that will later be difficult to fully capture in the analysis, but that I, as a researcher, at least tried to evoke or suggest. Thus, in the end, besides cutting up the texts of the interviews and creating certain categories ad hoc to carry out a "simple thematic analysis" (Burman, 2004, p. 81), I also tried to describe what the record -the transcription-, on its own, does not allow me to capture. That is, the interview experience as an event.

Following the qualitative principles of application and analysis of the interview, I carried out:

- In-depth interviews and focus groups with seven male and female participants, both from the first C.M. editions (2014-2015), as well as from the edition that was taking place at the time of the fieldwork (2017).

- Individual in-depth interviews with three officials and technicians institutionally linked to C.M. development.

- Individual interviews, with four directors and technicians from local entities, such as civic centres and youth centres, who at that time were involved in the management of activities related to C.M.

- In-depth individual interviews with three C.M. teachers and managers involved in the daily teaching-learning and program management activities. 
To safeguard the identity of the participants, I have not included detailed information about them (staff, teachers and students); nor are they identified by name. No demographic data are included. However, in a general way, it can be said that the majority of the staff and teachers are Spanish, while the students are of multiple origins: Spanish, Latin American and African. The musical styles represented in the program are equally diverse: hip hop, flamenco, rumba, rock, funk, soul, pop and classical music.

\section{Young People Stare Into the Abyss... and the Abyss Stares Back at Them}

The global economic crisis known as the "Great Recession" which imploded, but did not begin, in 2007 with the collapse of the US bank Lehman Brothers, represented a challenge and a "window of opportunity", as the business community uses to state, especially for young people whose hopes for the future were suddenly dashed. For example, with the economic crisis looming, the World Bank (2006) produced the "World Development Report 2007: Development and the Next Generation", a report that was particularly well publicized and whose agenda was disseminated in youth projects in post-crisis Europe.

Other globally influential agencies, such as Save the Children, the World Economic Forum, USAID, GTZ (Deutsche Gesellschaft für technische Zusammenarbeit), the Canadian International Development Agency or the UK Department for International Development participated in the drafting of the World Development Report 2007. As Sukarieh and Tannock (2008, p. 302) explain, this and most youth-oriented reports aim to "meet the needs and interests of neoliberalism rather than the needs and interests of the youth". Each report is aimed at giving guidelines to state programs, in order that they adapt youth-related content according to the elites' changing concerns which are usually related to economic crises or urban insecurity.

In Europe, the global economic crisis was already being pre-figured years before by a social crisis. Outraged young people from working class neighbourhoods ("Banlieus") took to the streets of Paris and other French cities to burn everything in riots that would last several months in 2005. The French riots would be followed by numerous spontaneous demonstrations of revulsion throughout Europe, with young people as the main actors. 2010 is a year in which Europe "burned": demonstrations, riots and/or looting in Milan, Rome, Dublin, London, Athens and Paris again. In 2011, again in London, there were hyper-mediatised riots, protests and looting that began in the Tottenham neighbourhood.

The stock market crash of 2008 had its national version in every country in the world. In Spain, the global recession was known simply as the "Spanish economic crisis", whose first macroeconomic symptoms began to be felt right in 2008. They finally dropped to "street level" in 2011 after the spectacular bursting of the real estate bubble, with thousands of citizens evicted due to non-payment of their mortgages and loans; a dramatic increase in unemployment, which was more pronounced among young people. In this sense, what analysts could observe at the time was that the global financial crisis engendered the expectation of a change towards a post-neoliberal regime that would never take place (Dean, 2014; Harvey, 2010; Konings, 2016; Peck, 2010).

The Spanish case can be seen as a grotesque example of the neoliberal recipe to "get out of the crisis" -or, in any case, to sink deeper into it. Governing the country during the hardest period of economic crisis Mariano Rajoy (2011-2018) of the right-wing Partido Popular (PP), authorized a massive bailout of the banks with public money. The situation of the Spanish youth under the crisis would be summarized in "two media archetypes". On the one hand, there were the ni-nis ("neither-nors": neither studying nor working). On the other hand, there were the indignados ("indignants"; Planas-Lladó, Soler-Masó, \& Feixa-Pàmpols, 2014, p. 553), a movement that took the streets of the main cities of the country with demonstrations and encampments in 2011. These would be known as the 15-M due to a massive demonstration on May 15, 2011 in Madrid. This movement would be the germ of Podemos, a new left-wing party that has governed the country since 2019 in coalition with the more socio-liberal, rather than center-left, Partido Socialista Obrero Español (PSOE).

In Barcelona, the massive encampment in Plaza Sol in Madrid would be replicated with a massive encampment in Plaza Catalunya, which had similar demands: to demand a change in the financial and neoliberal policies that dominate 
the Catalan, Spanish and European panorama. Catalonia had been for some time the advance guard in neoliberal policies such as the deregulation of banking or the privatization of the public sector, to which a rise in the tone of pro-independence demands would be added. The mandate of Artur Mas in Catalonia (2010-2016), of the Convergència i Unió party, a union of two right-wing parties, Catalanist and Christian Democrat formations, would be marked by the economic crisis in the autonomous community, the corruption trials of eminent politicians of Catalan nationalism, such as Jordi Pujol, and the parallel turn towards radical independence of a large part of the Catalan political elite led by the aforementioned president Artur Mas.

In this context of socioeconomic crisis, several interviewees coincided in pointing out a violent riot that took place in the Besòs strip of Barcelona, very much in line with the riots that occurred in the rest of the European countries, as the trigger for the government's concern to create a youth intervention program. A concern that would end up crystallising in the creation of C.M.:

"At the beginning of the previous term of office, a tragic event occurred in one of the neighbourhoods of the Besòs strip and a young man of Senegalese origin died in a street conflict [...] at the hands of a young man of gypsy ethnicity ${ }^{1}[\ldots]$ thus, this generates a lot of concern and tension between groups and an important concern on the part of the new government team that has just taken office and that raises [the] concern that in the areas of the Besòs neighbourhoods could appear, let's say, a focus of social conflict, we saw the problems of the Banlieu [in France] and we were concerned [...] then they decide to promote a strategy for the Besòs axis. Internal meetings are organised [and] the institutional dimension involves many actors: urban guards, districts, etc."

In other words, from its origin, the program is a tool to de-escalate social tension in the area and calm rowdy youth. Concerned about what happened in the Besòs strip, a strategy promoted by many actors was coordinated by J.V. with the advice of D.J. This was one of the ideologists of C.M. and founder of "Promocions, Xarxa de coneixements", a private organization of the third sector that aims to "promote and encourage the local social and solidarity economy, as well as the creation of companies and job training and integration".

From the first meetings, a "motor group" in charge of developing a "vulnerability index" of the Besòs strip was defined, and a small document was published afterwards with the results of the corresponding study ${ }^{3}$. It was from this work that what would later be known as the "Projecte de promoció, cohesió social i desenvolupament de la Franja Besòs de Barcelona" ("Promotion project, social cohesion and development of the Besòs strip in Barcelona") (Ajuntament de Barcelona, 2013) took shape. This document consists of five "demo actions" that structure the interventions that would be carried out on the Besòs axis. Action number four, "Cultura, Música i Arts: Estratègia de dinamització socioeconòmica $i$ cohesió social" ("Culture, Music and Arts: Strategy for socioeconomic dynamization and social cohesion"), is the one that would eventually be the model document that gave rise to C.M., which operated jointly between the "Direcció de Serveis d'Estratègia i lnnovació' de l'Àrea de Qualitat de Vida, Igualtat i Esports" ("Directorate of Strategy and Innovation Services for the Quality of Life, Equality and Sports Areas") and the music academy 'El Taller de Músics'.

The first two editions of C.M. (years 2014 and 2015) were framed within the so-called "Besòs strip strategy" -a public intervention program that included other initiatives in the area- offering musical training and support to young talents from the districts of Sant Martí, Sant Andreu and Nou Barris. These two programs were carried out prior to the current Barcelona En Comút municipal administration's entry into government.

1) It refers to the shooting and murder of Ibrahima Dyei by three "gypsy-ethnic" residents of the Besòs neighborhood in the District of Sant Martí, which resulted in a day of street riots and clashes with the autonomous police of Catalonia [the 'Mossos d'Esquadra']. See Baquero and Muñoz (2012).

2) Interview J.V. Letters indicate participant identity.

3) Interview J.V.

4) Left-wing political platform that brings together various parties and independent politicians that emerged as a result of the 15-M movement in its Barcelona branch. Strongly linked to Podemos, but differentiated in both ideological and strategic nuances. In 2015, they would bring Ada Colau to power as mayor of Barcelona. It was the first time in the history of the city that a social activist came to power. 
Throughout 2017, while the field work for this project was being conducted, C.M. proposed to carry out a re-edition of the project by "making the leap" from a municipal project to a metropolitan one. This would extend the intervention to disadvantaged neighbourhoods and areas in other municipalities of the Baix Besòs (Sant Adrià del Besòs, Badalona, Santa Coloma de Gramenet, and Montcada i Reixac) and would imply that Barcelona City Council would stop financing and directing the project. As a result, the project would be left in the hands of the Besòs Consortium, which integrates all the municipalities and agents under the principle of "shared responsibility"5 within the framework of the great commitment to metropolitan transformation for the coming years: "the new Besòs Axis strategy".

Ever since the gestation of the idea of C.M., it had been suggested that this project's viability would be inseparable from its capacity to settle and weave territorial networks. This was partly due to the fact that C.M. faced the perception of municipalities and local agents that "Barcelona colonises us" ${ }^{\text {. }}$. However, the results ended up not being the desired ones, and the strategy of "relinking Cabal" with this "network of cooperation between public, community, private and cooperative agents, etc." was a failure. Interrelating with the "valid interlocutors in each community"7 was thus deemed as vital.

Likewise, some of the ideologists perceived that the project was straying in the search for musical excellence. According to them, the project was thus losing its transversal perspective which included working on territorial concerns, the community and achieving the so-called "social cohesion", the main objective in the Governance of the Metropolitan Area of Barcelona (Ajuntament de Barcelona, 2013). How to ensure that these objectives, being so broad, would not be lost? In the end, the invoked answer, which was repeated like a mantra, was that everything would be solved by "weaving territorial ties". This "magic solution" turned out to be more discursive than real, since "as project managers we haven't put enough thought on how to ensure this part"'.

For example: in the Baró de Viver neighbourhood, only one musical group, which ended up not passing the "quality filter", participated in the call for C.M. The entry form for the program was filled out by the director of the Civic Center herself in her office, since none of the members of the group knew how to fill out an online form. This detail, which may seem insignificant, actually implies a whole series of barriers which the program had not considered. To participate in C.M. you have to "have the ability to explain what you want and what you do," says B.L., according to whom the reality of the place is such that even filling out the form "is already an issue". Starting with Internet access, but also because "if you have never filled out a form before, you see the first page and it scares you". In B.L.'s opinion, "if there were other mechanisms, these deficits could be remedied"10.

On the other end of the experience we would find the "Kasal Roquetes", the toponym of the neighbourhood to which it belongs. They have been a reference in the use of music as a "tool for social transformation" for many years. The model in Roquetes, unlike that of other cultural facilities, tends towards self-management. That is to say, it is not managed by an external company: "the walls are public, but the work is self-managed" as I.G., one of the Casal's managers ${ }^{11}$, comments. The Casal's penetration at the community level is very important, especially among young people. With this solid base work, it is not surprising that the "Kasal Roquetes" is one of the main seedbeds for C.M. Neither is it surprising that the most successful musicians, that is those who attract the community the most, as is the case of Monique Makon, have emerged from said Casal. However, in I.G.'s opinion, the merit is due to the grassroots work at Casal, rather than to C.M. itself:

\footnotetext{
5) Interview D.J.

6) Interview J.V.

7) Interview D.J.

8) Ibidem.

9) Interview $M$.

10) Interview B.L.

11) Interview I.G.
} 
"At Casal we have always worked together on the artistic and social aspects. The social-community return is very big, but Cabal has nothing to do with this process. Nor has [Cabal] had a negative influence, they have simply treated each other with respect." ${ }^{12}$

Even more critical of how C.M. has fit into the territories is G.M., a facilitator of the "Zona Nord" Civic Center in the Ciutat Meridiana neighbourhood. In her opinion, not only is there no active participation of local agents in the design of C.M., there is also no concern for "socialising the program's community objectives" ${ }^{13}$. For her, C.M. does not intend to have a greater impact beyond some reinforcement of musical skills at a strictly personal level ${ }^{14}$. From the context of Ciutat Meridiana, it is not apparent what C.M. has done to "weave networks" or "get involved with other projects emanating from the territory"15. In the same way, it can be said that it has "empowered itself individually" but "it has not entered into the gear of the territory. It doesn't care about [the territory]"16. In fact, rather than reverting to the community, it has served as a way of "[getting the children] out of the neighbourhood"17. In other words, in the end, C.M. expels talent without generating a social return:

"The positive effects of Cabal Musical are strictly at an individual level, of the groups that participate, but not at the community level. Perhaps there may be a community benefit, but in a very indirect way, such as: 'if a young person is well, their family is well, they get better at school and let's say, for 'community health' '[...] but the project has no impact on the community, nothing, although it could. There is no social return, it is an individual return. Something more global, no. It has no impact."”18

But even in the aspects related to artistic growth, it is very difficult for a public program with time limitations to introduce the same parameters in terms of technical rigor that one would have, for example, at a private school of higher studies in music. In this sense, the objective of C.M. cannot be "artistic excellence" either, and what has been attempted is rather an intermediate route, "the reinforcement of talent"19. On paper at least, there seems to be, let's call it a "bicephality" manifested in some objectives emphasising social aspects, social cohesion or empowerment for example, while in the programmatic aspect a certain entrepreneurial character is imposed. It could be said that the social objectives have been relegated to a "merely discursive" role, as recognised in the program itself ${ }^{20}$.

\section{A New Cycle in the Ideological Production of Young People}

Currently, young people are being bombarded with ideologising messages aimed at entrenching the neoliberal agenda in the new generations. This is done to such an extent that it represents the most important "vehicle for calming the ideological challenge and rebuilding a consensus under the neoliberal tent" (Sukarieh \& Tannock, 2008, p. 308). The neoliberal ideology described by David Harvey $(2000,2005)$ could be synthesised as a set of discourses and discursive artefacts that postulate that social welfare can only be achieved through the liberation of individual entrepreneurial forces, which had been previously repressed by the State; but paradoxically, it is up to the State itself to favour and build the conditions for the emergence of that type of hyper-individualistic subjectivity. Therefore, it would be a mistake to look at neoliberalism only as an economic-political system and to ignore the anthropological revolution it intends.

\footnotetext{
12) Ibidem.

13) Interview G.M.

14) Ibidem.

15) Ibidem.

16) Ibidem.

17) Ibidem.

18) Interview G.M.

19) Interview $M$.

20) Ibidem.
} 
The concept of ideology is often caricatured as "false consciousness". This I consider a theoretical error: the subjects are not far from "reality" because of ideology, whatever we mean by it. These kinds of naively realistic interpretations are partly to blame for the fact that nowadays the concept of Ideology is something "out of fashion" (Roggerone, 2015). However, from the Marxist philosophy of psychoanalytic inspiration, in the already classical perspective of Althusser (2014, pp. 112-120), and contemporarily in Žižek $(1989,2008)$, ideology is a producer rather than a subtractor of realities. Althusser (2014) opposes the idea that "ideology is pure illusion, pure dream, that is, nothing" (p. 213), which would be a "purely negative thesis" (p. 214).

If it is not a negative thesis, what is ideology, then? For Žižek, Marxists have historically understood "ideology" in three senses: "ideology as a complex of ideas", "ideology in its external appearance" and "the 'spontaneous' ideology that operates in the center of social 'reality' itself" (1989, p. 16). The elementary formulation of a Marxist theory of Ideology needs to be "extracted" from Marx's theory of "commodity fetishism" (Jappe, 2014; Žižek, 1989, 2008).

For Marx, the act of capitalist exchange necessarily implies the division of consciousness between "practical consciousness" and "theoretical consciousness." For mercantile exchange to function, there has to be a basic blindness where the abstract dimension of the value of a commodity is obviated; it is a "hidden mystery" (Marx, 2015, p. 75) in the very form of the commodity, rather than in the individual consciousness of those who participate in the exchange; in this sense, it is "this finished form -the money form- of the commodity world that hides the social character of private labor under the cloak of things" (Marx, 2015, p. 76). That is to say, the illusion is not in the consciousness but in the acts; otherwise, it would only be enough to "think correctly" for the illusory veil of capitalist reality to fall. We know that this is not so, since it has an unconscious character: individuals "do not know it, but they do it" (Marx, 2015, p. 74).

\section{"[...] 'Ideological' is not the 'false consciousness' of a (social) being but this being itself in so far as it is supported by 'false consciousness'" (Žižek, 1989, pp. 15-16).}

For Žižek "reality cannot be reproduced without this so-called ideological mystification" (1989, p. 56). The dominant Ideology of each epoch, not only alienates, but also produces the alienating reality. Conceptual production is part of the ideological practices of the "Ideological Apparatuses of the State" (Althusser, 2014) that create this reality as something taken for granted. Concepts such as "empowerment" or "resilience" appear to us as something neutral and "natural", however, they have been manufactured in the factories of the Ideological Apparatuses, entities that, as Althusser (2014) explains, are disseminated and can be public or private.

Regarding youth, these concepts are taught through programs, such as the aforementioned "World Development Report 2007: Development and the Next Generation" of the World Bank, the most recent "What Europe does for me?", with a section on "Youth Empowerment"; local institutions, in municipal development plans such as "Barcelona: building a resilient city" where the "promotion and recognition of personal resilience" is mentioned (Ajuntament de Barcelona, 2013) or in "the Strategy for inclusion and reduction of social inequalities of Barcelona 2017-2027" where one of the guiding principles is the "personal empowerment" of young people.

In academic literature, "empoderamiento" has been understood as the process (and result) that goes from "not having" to "having" power (Morales, 2016); this is an Anglicism from the English term "empowerment", which, in its use in Spanish, generates a great deal of confusion. For example, the term refers simultaneously to both the fact of possessing power and the process of "learning" to "have power". In other words, it confuses both the cause and the effect of "having power" in a person or community. As a cause, empowerment is assumed to have a directionality, the product of an extrinsic and centripetal movement, that is, the application of a force that is transferred from an institutional centrality, to which "a power" is attributed, to a periphery to which the opposite, "a weakness", is attributed.

In fact, in the field of community psychology, empowerment, a term coined by Rappaport (1981), was conceptualised as a process through which not only individuals but also communities acquire control over their lives, from a psychological perspective but with "a concern for real social influence, political power and legal rights" (Rappaport, 1987, p. 121). In the 1970s, prior to the use of the concept of empowerment, Latin American community psychology used terms such as "fortalecimiento" or "potenciación" with a meaning similar to Rappaport's community empowerment (Montero, 2003).

In the current context, especially in so-called developing countries or in the poor neighbourhoods of developed countries, NGOs, companies and aid agencies employ terms such as empowerment to disguise "moralistic tropes and modes of activism originating in the late eighteenth century" that reproduce the same paternalistic relationships that 
existed between colonists and the colonised (Martínez \& Libal, 2011, p. 167). Thus, Melinda Gates, wife of tycoon Bill Gates, has a foundation through which she "empowers" women in India by sending them a box of chickens (Cronin-Furman, Gowrinathan, \& Zakaria, 2017, p. 1).

The success of a term like empowerment is partly explained by the fact that it replicates the "white saviour" style where "complexity is eschewed in favor of simple stories of abject victimisation that is far more appealing to Western audiences" (Cronin-Furman, Gowrinathan, \& Zakaria, 2017, p. 17). In this context, there are those who raise the paradox (and the problem) of what the point of "empowering the disempowered" ${ }^{21}$ is. At best, this symbolically empowers communities that have no objective power. In most cases however, this empowerment is synonymous with the application of self-improvement and self-esteem building techniques. One of the many contradictions is that, in vulnerable contexts individuals can only count on themselves; that is, they already have individual expertise and empowerment, so would it not be more necessary to strengthen public rather than personal empowerment?

In the case of Barcelona, "empowering" social programs are, according to Morales (2016, p. 28), adapted to a neoliberal model where "the market economy is presented as the solution to all problems". The objective of empowerment would thus be that "individuals make the best decisions, from a rational perspective", considering the management of social inequality and poverty at the individual level, rather than their disappearance.

Furthermore, from an ideological perspective, C.M. could be described as a public project of training and dissemination of artistic talent using musical language as a tool for the promotion of resilience and empowerment of young people in a "situation of vulnerability" in the context of the economic and social crisis of the 'Besòs Axis' (Taller de Músics, 2016). In this context, "some entrepreneurs" coin or incentivize a series of actions oriented to what has been called "social entrepreneurship" or "companies with social impact", without denying an operation of "face-washing of certain banking institutions or certain companies" pointed out as responsible for the crisis $^{22}$.

Taken in this way, the strategy would be framed as the provision of socio-cultural tools for the young people of this economically depressed region to acquire skills (psychological and attitudinal) so that they can overcome the crisis, as well as adapt and develop autonomous productive projects. Ideally, what the program would try to do, at least from the perspective of its ideologues, would be to foster the capacity to generate "protective factors" in environments of high exposure to risk and vulnerability. These protective factors are what has been known for some time now, not without ambiguity, as "resilience".

According to the Salvat Encyclopedic Dictionary, the word comes from the Latin resilere, which means "to leap upward, to jump back in by jumping, to rebound, to turn away or deviate" (Rodríguez, 2014, p. 53). "Resilience" was originally used as a metaphor referring to the capacity of metals to resist rupture due to shock or pressure. When we talk about resilience, a concept introduced in the Social Sciences by psychologist Michael Rutter, we thus talk about a metaphor which, from a psychological perspective, has been interpreted as the supposed psychological invulnerability that certain subjects possess despite the hostile or emotionally deficient environments in which they have grown up (Rutter, Cox, Tupling, Berger, \& Yule, 1975); later, Rutter (1993) himself reformulated the concept as a human capacity that develops in the triangle formed by three concepts: vulnerability, risk and protective mechanisms. Rather than an innate capacity, it is something that can be learned. In the case of C.M., the intention is that these resilient factors are obtained through culture.

The intrinsic relationship between resilience and empowerment results from the former being that 'thing' that is acquired through the latter. For Belykh (2018, p. 259), the terms empowerment and resilience are closely linked, insofar as empowerment is a tool used to achieve "a personal growth coming from adversity, development of intra and interpersonal resilient resources, a transformation and social activation of the resilient subject". This same instrumental relationship between empowerment and resilience is found in other authors, such as Forés and Grané (2008).

Brad Evans and Julian Reid unravel the ideological underpinnings behind the success of the concept "resilience". First of all, they point out something very important: that behind its apparent technical aspect, there hides a type of political lexicon, in short, an ideology:

21) Cynthia Ramírez (October 12th, 2017). "El problema de empoderarse sin tener poder". Letras Libres

22) Interview $M$. 
"The neoliberal subject is not a subject who can conceive of the possibility of insuring themselves against their dangers. They believe in the necessity of life as a permanent struggle of adaptation to dangers. Certainly, since the subject in resilience accepts the dangerousness of the world in which they live as a condition for taking part in that world and the necessity of the mandate to change itself in accordance with the dangers that are now presupposed to be endemic, the construction of neoliberal subjects involves the deliberate disabling of the aspirations to security that people might otherwise promote, and their replacement by adaptive ones." (Evans \& Reid, 2014, p. 70)

The resilient subject is a radical individualist. But an individualist at the end of time, possessed by a Mad Max subjectivity. He succeeds when he adapts and survives. In this sense, he may even appear to be a rebel, since he clashes with the conservatism of classical liberalism which, at one point, believed in the social reproduction of a community. Resilient subjectivity is ideal for neoliberal governance, insofar as it reduces the human to its merely biological characteristics of adaptation, which foretell "the twilight of the social" (Giroux, 2012, p. 36).

\section{An 'Operación Triunfo' for the Poor}

There is something twilight-esque about social concerns in reality shows like 'Operación Triunfo' (OT) ${ }^{23}$, where contestants compete among themselves to see which one is the most talented in the eyes of a jury that evaluates them. In these television programs, life itself is transformed into a contest where only one comes out the winner. Although the affective life seems very rich and spontaneous among contestants, the attraction to these programs lies in knowing that most of the contestants will lose and only one will emerge victorious, after their personal drama has been spectacularised.

Friendliness, charisma, as well as artistic talent or even more than this, personality, becomes an asset, a capital, for reality shows. Guy Debord (2015) anticipated by half a century the boom of capitalist accumulation through the co-optation of signs and social relations carried out by 'Big Tech' companies such as Facebook, which incite the pornographic exhibition of the self on social networks and whose model seems to be none other than that of the reality show. Debord was the theorist of reality TV avant la lettre; he anticipated how presence (the pure image), not talent or art, is at the basis of value production in "the society of the spectacle":

"The spectacle presents itself as an enormous positivity that is indisputable and inaccessible. It says no more than this: 'what appears is good, it is good what appears'" (p. 39).

C.M. is striking for its format, a sort of an 'Operación Triunfo' for "the poor", where there is a very intense socialisation among people who did not know each other before. Another similar element is the type of talent show dynamics, where a jury evaluates the participants in each weekly presentation, which is similar to the presentations with triumphant winners of talent shows. As in OT, there is also a final concert. In its first edition there was a "winning" artist, regardless of whether C.M. had the explicit intention of crowning a single artist. The unusual mediatisation for a social development program is very remarkable. The program has been widely covered by the local media, especially by TV $3^{24}$. Some of its participants have become relatively famous figures in their neighbourhoods.

The most striking case is that of Cameroonian-born soul singer Monique Makón, a resident of Ciutat Meridiana. One of the program's hypotheses is that, if the participants' image is constructed around the idea of emerging "young stars" from disadvantaged backgrounds, there would be an empowering effect that would radiate to the rest of the young people of the Besòs strip; indeed, this is how the program's social objectives are justified ${ }^{25}$. The goal is to build a chain

23) 'Operación triunfo' is a reality show which first aired on Spain's TVE network in 2001. A music talent contest with public voting that originated Endemol's Star Academy franchise, the show aims to find the country's next pop music sensation. It would be the Hispanic equivalent of the 'American Idol' program in the United States of America.

24) Public and autonomic Television of Catalonia.

25) Interview J.V. 
of empowerment until "turning the Besòs into a success factor" ${ }^{26}$. Another one of the officials advising the program describes it as follows:

"When you go to a Cabal Musical concert, I believe that what you see, with respect to other types of concerts, you see how proposals that were at a very low level can rise to the highest level. From the artistic point of view, the presentation of these proposals should be taken care of. Being able to show this on stage is to identify references: 'that black girl who is on stage and I, who am from the neighbourhood, see her and think 'wow, she's a neighbour'. It generates a point of affinity and relationship. The goal is to achieve this."27

One of the dominant opinions among teachers and instructors of the Taller de Músics is that the program has given the children the possibility of accessing a "world" previously "unknown" to them. This generates a relative sense of social climbing among them, which is viewed positively by some teachers and somewhat more critically by others. In general, by rubbing shoulders with people from the professional music world and the media, it is believed that the participants will broaden their networks by connecting with social circles that were distant from them and acquiring what M. calls "relational capital"28. This is something that the beneficiaries appreciate and value, for example, the rapper S.T., from the second generation of C.M. He had always made music but had never had contact with the professional world. With C.M. he was able "to consider that music can be your lifestyle"29.

"Everyone knows where they come from. So, they [the Cabal boys] are aware that they would not have the resources to pay for something like this, but they want to 'become something more'. Most of them were working in things that did not fulfil them and now they see a future in music. There are some life stories that are more impressive than others. Like the case of M.M. whose family was about to be evicted. His parents were unable to provide for the family. Their water had been cut off: cool poverty energy" ${ }^{\prime \prime 3}$.

However, this reception, this pretended success, is distorted by a permanent feeling in the children that "they are being taken for a ride". The children feel spectacularised. This is something that constantly appears in the interviews: the hatred of their image mediatisation as 'resilient ghetto kids'. This discomfort with the spectacularisation of their poverty is transversal. That is, it is a comment that has emerged both in interviews and in focus groups, both in boys and girls, both in those who have already graduated from the program and in those who were studying it at the time of the research. This is what some of the boys think about it:

N.- "They always say that they are looking for people with few resources and I don't like to hear that. In advertising it always comes out, young people with few resources, 'from the ghetto', and I go, suuuure."'31

D.- "That's what I was thinking about today: they make us feel like poor people."

M.- "I mean, it doesn't bother me that they say it's for people of limited resources, because there may be people in Cabal who would like to enter because they could not afford it elsewhere. And that's perfect."

D.- "They give us a point of view (sic) as if we were picked up from the street, like a 'poor little puppy'. In social networks I see it like [...] I'll give you an example: it's like if someone gives 50

26) Ibidem.

27) Interview S.D.

28) Interview $M$.

29) Focus groups - Graduates

30) Interview A.P.

31) Focus Group - New Participants. All quotes from participants in this focus group. Letters indicate participants' identity. 
euros to a homeless person and then takes out a loudspeaker and says: 'hey, look, I gave 50 euros to this man.'

N.- "And television [...] I mean, the interviews, they always say 'of young people with few resources' from I don't know what area of Barcelona [...] With the artichoks [group developed in Cabal] that has come up and we laughed, because it makes us laugh."

S.- "Someone from TV3 once asked me: 'Hey, you, so what is life in the hood like?' I thought: 'Well what do you think life in the hood is going to be like? Like yours, asshole! It's a very American thing, like Operación Triunfo, looking for 'success stories.”'32

R.O.- "Monique Makon was tired of being asked about "her personal story" and not about her music.'

R.A.- "Her 'personal story' is not important. What is important is that Monique Makon has an unbelievable voice."

S.- "You can't change that mentality because it's in the culture, it's all very sensationalist. When I get an asshole journalist I tell them what they want to hear: 'yes, yes, the ghetto, the guns, the violence' [...] it's all lies. If they want shit I'll give them shit."

R.O.- "When we played at the Auditori, someone introduced us as 'the artists of the slums', and I went: okay, suuuure. It makes me laugh, it doesn't offend me at all, it seems absurd to me."

Although their exemplarity as "success stories" is perceived as something toxic, in their discourse they paradoxically stick to a meritocratic and triumphalist script. For example, in regard to their relationship with the music industry, they claim to cling to it, "despite all the difficulties" ${ }^{\prime 3}$, with a certain heroic mood. It is a gesture that Mark Fisher called "reflexive impotence" (Fisher, 2016, p. 49). This generation is more aware than ever that things are not going well but is incapable of doing anything else than actively collaborate in the reproduction of the status quo. This allows them to stay within the system and embrace "capitalist realism", which can be defined as "an over-identification with capital" (p. 35).

With his analysis of commodity fetishism, Marx helps us to reconstruct that the character of this "overlooked unconscious illusion" sustaining capitalism is none other than an "ideological fantasy" (Žižek, 1989, p. 61). This is perfectly visible in the case of the children of C.M. They recognise that the program sells them illusion only, but at the same time that illusion is indispensable for the program to sustain itself. The "ideological fantasy" of easy success is a material part of C.M. It is as real as the musical instruments they play. This is so, not because they "reason wrongly", but because they reason in line with a system where all hopes are placed on individual energies and wills through constant calls for empowerment, resilience and "getting ahead".

For the director of C.M., the ambivalent attitudes that the program arouses in young people and the noise it generates are not caused by the ideology of the program itself, but by the cognitive errors of the participants. It is their "false consciousness" that makes them "not realise" their condition of being excluded survivors (i.e., resilient), and therefore, of their privileged condition -what a paradox- having been touched by the grace of C.M.: "exclusion is a discourse that is all very well on paper, but nobody wants to be excluded, nobody wants to be marginalised, nobody wants to recognise themselves as such because these are stigmatising discourses" ${ }^{\prime 34}$.

The interlocutor does not recognise the discomfort of the children in the role of the heroic victim, their outright rejection of the stigmatised identity (Goffman, 2001) that has been foisted on them and sold by Cabal Musical. M. cannot hide all these series of contradictions that are so present and recognises one of the empowerment paradoxes: empowering implies selling the idea that the beneficiaries of the program had no power prior to the program, they were victims, reaffirming the stigma of "poor neighbourhood kids":

32) Focus Group - Graduates. All commentaries are for participants to this focus group. Letters indicate every participant identity.

33) Focus Group - Graduates

34) Interview $M$. 
"[...] we also saw this contradiction, when it came to selling the project, we did not know whether to 'sell pity or sell talent'. 35

And he continues:

"We had a hard time conveying that: telling them that they were there because they needed it or [otherwise] they would have no way to have access to it [musical success]."36

Rather than a choice between "selling grief or selling talent", the C.M. program has been very adept at selling grief through talent and making it a program with a high emotional charge but little professional outlet, creating great frustration, if not false hopes, among the student body, which will probably also end in frustration in the long run. Paradoxically, the greatest concern for managers came not from those students who were more cynical about the program's intentions, but from those who took it more seriously than the officials themselves would have liked. One example is that of R.O. who was studying and working as a nurse but, influenced by C.M., quit her professional activity. Her decision generated concern in her family about a very unrealistic outlook for her daughter in the music industry. ${ }^{37}$

For cases like these, the directors have considered the dubious solution of rejecting those candidates who do not have jobs or studies and directing them to "a job placement or youth guarantee program, some kind of program that would guarantee that they do not generate expectations in music, to make them aware that music is not such an easy job opportunity"38.

"You have to counter the discourse of easy success. Because Operación Triunfo has done a lot of damage. Some people inevitably have this in their backpack. And in the discourse of Art there is also a lot of this, bringing the discourse of 'I made myself' ${ }^{39}$.

Faced with this series of contradictions, the Program's response has been to "throw balls out of bonds" (i.e., to avoid or dodge the actual problem): if the beneficiaries reject the stigma of "poor neighbourhood kids", they are attributed a false consciousness; if they allow themselves to be imbued by Cabal Musical's ideology of empowerment, then they are being co-opted by the easy success discourse of Operación Triunfo; if they only ask for more music lessons and to be allowed to play, they are seen as "ungrateful" people who do not understand the significance of a program that "goes beyond music".

\section{Discussion: Resilient Entrepreneurship or the Ideology of Survivalist Capitalism}

The young C.M. participants were attracted to the program by the possibility of perfecting their musical skills and meeting young people with the same interests as themselves. In the end, what they found was a program that was not entirely a music education program, but neither was it a job placement program, much less a network to strengthen the music scene in the neighbourhoods. It was a bet on individual development through music with certain elements of entrepreneurial training. Very much along the lines of the very in fashion business coaching (Chávez, 2012), the young people have been emotionally motivated to develop their own brands, in this case musical ones, rather than being taught musical technique.

For these young people, music is the central element that motivated them to continue, however there was a feeling that time was being wasted on secondary issues: why not simply teach them musical technique? Is it a luxury for the children of the working class to be trained under the philosophy of "art for art's sake"? Can you imagine a kid who

35) Ibidem.

36) Ibidem.

37) Focs Group - Graduate (15.19)

38) Interview M. (12.20)

39) Interview M (12.18) 
lives in a bourgeois neighbourhood and who wants to perfect their guitar technique ending up being given talks on self-esteem and workshops on the use of social networks? Of course not. It is also clear that the bourgeois kid would pay for those kinds of lessons, while the working-class kids gets them for "free". Or maybe the lessons are not so free with the whole entrepreneurial, 'resilient' and supposedly social coating being the price that the working-class youth must pay to be able to get closer to art through public programs. That is to say, the payment consists in allowing themselves to be ideologised.

As already analysed throughout this article, ideologisation would consist in learning neoliberal rationality through business values, which forces one to metabolise "risk as a private good" (Evans \& Reid, 2014, p. 43). To create the ideal of the resilient subject, a new pact with the State is necessary, through which the subject accepts to be systematically trained in the strengthening of their subjectivity, to be able to "tolerate and anticipate all kinds of disturbances in a complex world, without this implying the collapse" (Lentzos \& Rose, 2009, p. 243) of not only the body as a productive entity, but also that of the mind, both comprising a system that has been made fragile vis-a-vis vulnerability, which in turn is understood as the only possible status quo of a world in crisis.

In the end, the social failure of the program would not be in its alleged internal contradictions but in its absolute coherence with what a socio-liberal program seeks in the 21st century: to make individuals responsible for the resolution of the social crises caused by the capitalist system itself. In this sense, the maintenance of security and the reproduction of life has been reformulated as a strictly individual matter (Evans \& Reid, 2014). In media and websites oriented towards business marketing, there is increasing talk of "resilient entrepreneurs", a business philosophy that is more than eloquent:

"Human nature seeks to avoid pain and seek pleasure, but entrepreneurs are a different breed. They take risks where others play it safe. They see problems and answers where others see status quo. They reject comfort zones in the name of progress, even when it means potential risk."40

Using empowerment as a method, the C.M. program is aimed at training resilient entrepreneurs, which we could simply call entrepresilients, since every entrepreneur is obliged to be resilient. Entrepresilients are the martyrs of capitalism in its unbridled and savage stage. They do not believe in free enterprise with the same ardor as the classic capitalists, but "they have no other choice". This seems to be C.M.'s case:

"[...] in the end, entrepreneurship in the artistic field is complicated, because, let's see, the artist is always an entrepreneur, but they are always a precarious entrepreneur. With the dismantling of the medium-sized music industry in this country, the only thing left is the music industry of the big companies, to which only certain musicians have access, the remaining have to start with entrepreneurship, so in a project like this [Cabal Musical], this is combined with public support, which is one of the strategies in a crisis situation. So, in that sense it is bicephalous in that, on the one hand, there is entrepreneurship and the involvement of the institutions, not as providers of employment -but almost so- and of social transformation and community empowerment, but, on the other hand, we also have to commit ourselves to the artistic growth of the participants.... how does all this coexist? It's very complicated."41

Under the ideology of entrepresilient capitalism, even the conception of time itself would change. As Bauman (2007, p. 52) explains, in modern capitalism the dichotomy between the "linear time" of history and the "cyclical time" of everyday life is broken. Since there is no future, both times merge into "monads closed in on themselves". Thus, life is left naked, as a merely biological process, devoid of meaning, in an endless chain of present instants of adaptation to that which is new; changes that, as it is understood, will be even more catastrophic. This is a new twist in the construction of capitalist subjectivities where survival becomes the resigned ultimate goal of our human condition.

40) Dustin Christensen (March 13th, 2018). "El emprendedor resiliente: Cómo hacerse más fuerte ante el fracaso". Foundr. Author’s translation

41) Interview $M$. 
Funding: The author has no funding to report.

Acknowledgments: The author has no additional (i.e., non-financial) support to report.

Competing Interests: The author has declared that no competing interests exist.

\section{References}

Ajuntament de Barcelona. (2013). Mesura de govern 20x27. Accions per enfortir la cohesió social als barris de Barcelona. Tinència d'Alcaldia de Qualitat de Vida, Igualtat i Esports. Retrieved from https://bcnroc.ajuntament.barcelona.cat/jspui/bitstream/11703/84768/1/12958.pdf

Althusser, L. (2014). On the reproduction of capitalism: Ideology and ideological state apparatuses. London, United Kingdom: Verso. Baquero, A., \& Muñoz, M. (2012, January 5). La muerte de un senegalés desata un conflicto de convivencia en el Besòs. El Periódico. Retrieved from https://www.elperiodico.com/es/barcelona/20120105/la-muerte-de-un-senegales-desata-un-conflicto-de-convivencia-en-elbesos-1304082

Bauman, Z. (2007). Vida de consumo. Mexico City, Mexico: Fondo de Cultura Económica.

Belykh, A. (2018). Resiliencia e inteligencia emocional: conceptos complementarios para empoderar al estudiante. Revista Latinoamericana de Estudios Educativos, 48(1), 255-282. https://doi.org/10.48102/rlee.2018.48.1.81

Burman, E. (2004). La entrevista. In P. Banister, E. Burman, I. Parker, M. Taylor, \& C. Tindall (Eds.), Métodos cualitativos en psicología. Una guía para la investigación (pp. 71-97). Guadalajara, Mexico: Universidad de Guadalajara.

Chávez, N. (2012). La gestión por competencias y ejercicio del coaching empresarial, dos estrategias internas para la organización. Pensamiento \& Gestión, 33(1), 140-161.

Christensen, D. (2018, March 13). The resilient entrepreneur: How to become stronger in the face of failure. Foundr. Retrieved from https://foundr.com/building-resilience-entrepreneur

Cronin-Furman, K., Gowrinathan, N., \& Zakaria, R. (2017). Emissaries of empowerment. New York, NY, USA: The City College of New York.

Dean, M. (2014). Rethinking neoliberalism. Journal of Sociology, 50(2), 150-163. https://doi.org/10.1177/1440783312442256

Debord, G. (2015). La sociedad del espectáculo. Valencia, Spain: pre-textos.

Evans, B., \& Reid, J. (2014). Una vida en resiliencia: el arte de vivir en peligro. Mexico City, Mexico: Fondo de Cultura Económica.

Fisher, M. (2016). Realismo capitalista ¿no hay alternativa? Buenos Aires, Argentina: Caja Negra.

Forés, A., \& Grané, J. (2008). La resiliencia: Crecer desde la adversidad. Barcelona, Spain: Plataforma Actual.

Giroux, H. (2012). Twilight of the social. Boulder, CO, USA: Paradigm.

Goffman, E. (2001). Estigma. La identidad deteriorada. Buenos Aires, Argentina: Amorrortu.

Harvey, D. (2000). Espacios del capital. Hacia una geografía crítica. Madrid, Spain: Akal.

Harvey, D. (2005). Breve Historia del Neoliberalismo. Madrid, Spain: Akal.

Harvey, D. (2010). The enigma of capital and the crises of capitalism. Oxford, United Kingdom: Oxford University Press.

Jappe, A. (2014). De lo que es el fetichismo de la mercancía y sobre si podremos librarnos de él. In K. Marx, El fetichismo de la mercancía (y su secreto) (pp. 1-15). La Rioja, Spain: Pepitas de calabaza.

Konings, M. (2016). Governing the system: Risk, finance, and neoliberal reason. European fournal of International Relations, 22(2), 268-288. https://doi.org/10.1177/1354066115593393

La Hidra Cooperativa. (2018). Evaluación integral del proyecto 'Cabal Musical'. Barcelona, Spain: Author.

Lentzos, F., \& Rose, N. (2009). Governing insecurity: Contingency planning, protection, resilience. Economy and Society, 38(2), $230-254$. https://doi.org/10.1080/03085140902786611

Martínez, S., \& Libal, K. (2011). Introduction: The gender of humanitarian narrative. Humanity: An International fournal of Human Rights, Humanitarianism, and Development, 2(2), 161-170. https://doi.org/10.1353/hum.2011.0020

Marx, K. (2015). El Capital, tomo 1: crítica de la economía política. Mexico City, Mexico: Fondo de Cultura Económica. 
Montero, M. (2003). El fortalecimiento en la comunidad. In M. Montero (Ed.), Teoría y práctica de la psicología comunitaria. La tensión entre comunidad y sociedad (pp. 59-92). Buenos Aires, Argentina: Paidos.

Morales, E. (2016). Empoderamiento y transformación de las relaciones de poder: un análisis crítico de los procesos institucionales de participación ciudadana (Tesis Doctoral). Universidad Autónoma de Barcelona, Barcelona, Spain.

Parker, I. (2004a). Análisis del discurso. In P. Banister, E. Burman, I. Parker, M. Taylor, \& C. Tindall (Eds.), Métodos cualitativos en psicología. Una guía para la investigación (pp. 121-141). Guadalajara, Mexico: Universidad de Guadalajara.

Parker, I. (2004b). Investigación cualitativa. In P. Banister, E. Burman, I. Parker, M. Taylor, \& C. Tindall (Eds.), Métodos cualitativos en psicología. Una guía para la investigación (pp. 13-33). Guadalajara, Mexico: Universidad de Guadalajara.

Peck, J. (2010). Zombie neoliberalism and the ambidextrous state. Theoretical Criminology, 14(1), 104-110. https://doi.org/10.1177/1362480609352784

Planas-Lladó, A., Soler-Masó, P., \& Feixa-Pàmpols, C. (2014). Juventud, políticas públicas y crisis en España: ¿Triángulo mágico o triángulo de las Bermudas? Revista Latinoamericana de Ciencias Sociales. Niñez y Juventud, 12(2), 551-564.

Ramírez, C. (2017, October 12). El problema de empoderarse sin tener poder. Letras Libres. Retrieved from https:/www.letraslibres.com/espana-mexico/politica/el-problema-empoderarse-sin-tener-poder

Rappaport, J. (1981). In praise of paradox: A social policy of empowerment over prevention. American fournal of Community Psychology, 9, 1-25. https://doi.org/10.1007/BF00896357

Rappaport, J. (1987). Terms of empowerment/exemplars of prevention: Toward a theory for community psychology. American fournal of Community Psychology, 15(2), 121-148. https://doi.org/10.1007/BF00919275

Rodríguez, R. (2014). La resiliencia y su instauración en el discurso de la psicología: un imaginario del discurso del amo y la histérica. Revista Vanguardia Psicológica, 5(1), 50-59.

Roggerone, S. (2015). Lo saben, pero lo hacen. Slavoj žižek y la persistencia de la crítica de la ideología. Revista Pilquen: Sección Ciencias Sociales, 18(3), 15-35.

Rutter, M. (1993). Resilience: Some conceptual considerations. fournal of Adolescent Health, 14(8), 626-631. https://doi.org/10.1016/1054-139X(93)90196-V

Rutter, M., Cox, A., Tupling, C., Berger, M., \& Yule, W. (1975). Attainment and adjustment in two geographical areas: The prevalence of psychiatric disorder. British fournal of Psychiatry, 126, 493-509. https://doi.org/10.1192/bjp.126.6.493

Sukarieh, M., \& Tannock, S. (2008). In the best interests of youth or neoliberalism? The World Bank and the New Global Youth Empowerment Project. Fournal of Youth Studies, 11(3), 301-312. https://doi.org/10.1080/13676260801946431

Taller de Músics (2016). Cabal Musical. Impulsant el talent musical als barris. Projecte 2016-2017. Barcelona, Spain: Author. Vázquez, F. (1994). Análisis de contenido categorial: el análisis temático. Barcelona, Spain: Universidad Autónoma de Barcelona. World Bank. (2006). World development report 2007: Development and the next generation. Washington, DC, USA: World Bank. Žižek, S. (1989). The sublime object of Ideology. London, United Kingdom: Verso.

Žižek, S. (2008). "El espectro de la ideología”. In S. Žižek (Ed.), Ideología. Un mapa de la cuestión (pp. 7-42). Buenos Aires, Argentina: Fondo de Cultura Económica. 